\title{
Effect of Distribution Channels, Service Quality and Product Quality on Purchase Decisions at PT Sumatra Sukses Jaya (FDR Tire Distributor)
}

\author{
Stewen $^{1}$, Andre Fitriano ${ }^{2}$, Winer Antono ${ }^{3}$, Tommy Wijaya ${ }^{4}$ \\ ${ }^{1,2,3,4}$ Universitas Prima Indonesia, Indonesia \\ Corresponding Author: Andre Fitriano
}

\begin{abstract}
The purpose of this study was to test and analyze distribution channels, service quality, product quality on purchase decisions at PT Sumatra Sukses Jaya. The phenomenon of a decrease in purchasing decisions, delays in distribution to customers, service quality that still gets complaints from customers and the existence of product returns from product quality that occur are the background of this research. The sampling technique in this study used simple random sampling using the Slovin formula in determining the sample. The number of samples in this study was 115 people. In partial data testing, the variables of distribution channels, service quality, product quality show a positive and significant effect on each variable on purchase decisions at PT Sumatra Sukses Jaya. In testing the data analysis simultaneously, the variables of distribution channels, service quality, product quality showed a positive and significant effect on purchase decisions at PT Sumatra Sukses Jaya.
\end{abstract}

Keywords: Distribution Channels, Service Quality, Product Quality, Purchase Decisions

\section{INTRODUCTION}

The development of increasingly advanced technology and information makes companies must always innovate in maintaining competition with other companies. The right and correct strategy needs to be done in order to support product sales activities carried out by the company in influencing purchasing decisions in the company. Purchasing decisions are important things that need to be maintained by the company in order to support the company's ability to compete with other companies.

The phenomenon of a decrease in purchasing decisions, delays in distribution to customers, service quality that still gets complaints from customers and the existence of product returns from product quality that occur are the background of this research.

PT Sumatra Sukses Jaya is a company engaged in the distribution of FDR tires. Purchase decisions are decisions made by consumers in choosing the product to be purchased. From the observation of data conducted by the company, there was a decline in sales in 2019. The lowest sales occurred in October of only $75.50 \%$ of the sales target of Rp4,000,000,000 per month. Meanwhile, sales from January to December tend to show a dominant decline compared to sales increases. This shows that there has been a decline in purchasing decisions in the company.

Distribution channel is a channel owned by the company in delivering ordered products to customers. The company's ability to provide delivery fleets and product order schedules will also affect the company's distribution capabilities to run well. From the observation of the company's distribution data, it can be seen that the company experiences delays in product delivery that occur every month. The highest number of delays occurred in 
September with 14 delays with 8 complaints.

Service quality is the perception received by consumers with the service received from the company. Based on observations made on the services provided by the company, complaints are still often received about the services provided by the company. The highest number of complaints occurred in July as many as 8 complaints of services provided. The reasons for complaints submitted by customers are employees who are not polite in communicating to customers, employees who do not answer incoming calls, employees who are often not careful in providing billing notes, and employees are considered slow in providing services.

Product quality is the advantage possessed by the product in its specifications and efforts to meet the expectations of consumers. Based on observations made at the company, there are still complaints about some products that are considered unable to meet expectations by customers. Product returns are still common every month. The highest number of product returns occurred in February as many as 25 pcs. The reasons for returning the product were found torn tires, cracked tires, tires with propellers. This shows that the product quality expected by customers has not been able to meet their expectations.

The purpose of this study was to test and analyze distribution channels, service quality, product quality on purchase decisions at PT Sumatra Sukses Jaya.

\section{LITERATURE REVIEW Distribution Channels}

According to Tjiptono and Chandra (2017:461), distribution and sales programs can be defined as programs consisting of various marketing activities that seek to expedite and facilitate the delivery of goods and services from producers to consumers.

\section{Service Quality}

According to Rangkuti (2013:103), service, namely the value related to the provision of services to consumers. The quality of service to these consumers needs to be continuously improved.

\section{Product Quality}

According to Manap (2016:255), product quality is everything that can be offered in the market to satisfy the needs and desires of consumers. Products consist of goods, services, experiences, events, people, places, ownership, organizations, information and ideas.

\section{Purchase Decisions}

According to Dharmaseta and Handoko (2016:99), the purchasing activity that appears is only a stage of the whole process of consumer behavior. The buying process consists of stages that begin with the introduction of needs and wants and do not stop after the purchase is made.

\section{Effect of Distribution Channels on Purchase Decisions}

According to Hasan (2013:173), future buying interest is strongly influenced by customer experience related to price, brand, promotion, advertising, supply chain, service mix, atmosphere, and location (place).

\section{Effect of Service Quality on Purchase Decisions}

According to Girard et al (2014:71), service to customers or better known as customer service is the key to the success of direct sales to consumers.

\section{Effect of Product Quality on Purchase Decisions}

According to Marwanto (2015:169), improving product quality is the most important thing. This is because the quality of a product greatly determines a consumer's decision to buy a product.

\section{RESEARCH METHODS}

This research will be conducted at PT Sumatra Sukses Jaya which is located at Komp. MIC, Jl. Pulau Menjangan C/16. The 
research time is planned from JulyDecember 2020.

This research approach is based on a quantitative approach because this research has a clear and orderly flow. This type of research is a type of quantitative descriptive research. The nature of this research is descriptive explanatory.

The populations in this study are customers at PT Sumatra Sukses Jaya with a total of 162 customers. The sampling technique in this study used simple random sampling using the Slovin formula in determining the sample. The number of samples in this study was 115 people.

According to Sujarweni (2014:149), "multiple linear regression is a regression that has one dependent variable and more than one independent variable." Can be calculated with the help of Statistical Product and Service Solution (SPSS) software. According to Ghozali (2013:98), the F statistical test basically shows whether all the independent variables included in the model have a simultaneous effect on the dependent variable. According to Sujarweni (2014:161), the t-test is an individual partial regression coefficient test used to determine whether the independent variable (X) individually affects the dependent variable (Y).

\section{RESULT}

\section{A General Description of the Company}

PT Sumatra Sukses Jaya is a company engaged in the distribution of FDR brand tires. FDR tires as one of the tire brands that are often used by motorcycles. With the increasing use of motorcycles from year to year, the needs for types of tires that are durable in use and of the best quality are also increasingly needed. Sales of PT Sumatra Sukses Jaya are carried out in the Medan city area with customers generally being motorcycle repair shops. In an effort to carry out business activities properly, the company also tries to implement the vision and mission that has been implemented.

Vision of PT Sumatra Sukses Jaya: To be at the forefront of providing FDR tires as one of the quality tires and the most in demand.

Mission of PT Sumatra Sukses Jaya:

1. Providing quality and guaranteed products for consumers.

2. Develop business with the support of good human resources.

\section{Respondent Characteristics}

From the dominant male sex are 70 people $(61 \%)$ and 45 people (39\%). The percentage of male dominant respondents shows that the dominant customer is male who understands more about the use of motorcycle tires.

From the subscription period, it can be seen that the dominant is 1-3 years with a percentage of 60 people (52\%), 1 year as many as 22 people (19\%), over 4 years as many as 33 people (29\%). This shows that the dominant age is 1-3 years with customers who have been dominant for a long time with the company and have become loyal customers between 1-3 years.

\section{Descriptive Statistical Analysis}

The following table below describes the value of $n$, the minimum value, the maximum value, the average value, the value of the standard deviation.

The table test of SPSS can be seen for the distribution channel variable with a value of 115 respondents, the mean of 31.9217 with the smallest value of 18 and the largest value of 44 with a standard deviation of 6.62683 .

Testing the table from SPSS can be seen for the service quality variable with a value of 115 respondents, the mean of 34.9217 with the smallest value of 23 and the largest value of 47 with a standard deviation of 5.06475 .

Testing the table from SPSS can be seen for the product quality variable with a sample of 115 respondents, a mean of 33.6870 with a minimum value of 20 and a maximum value of 44 units with a standard deviation of 5.12196.

From the results of the table tested from SPSS, it can be seen that the 
purchasing decision variable has a value of 115 respondents, the mean is 34,000 with the smallest value of 21 and the largest value of 45 units with a standard deviation of 5,16398 .

\section{Partial Hypothesis Testing (t Test)}

The $\mathrm{t}$ test is used to determine whether there is a significant (significant) relationship or influence between the independent variables partially on the dependent variable.

Table 1. Partial Hypothesis Testing (t Test)

\begin{tabular}{|c|c|c|c|c|c|c|}
\hline \multicolumn{7}{|c|}{ Coefficients $^{\mathrm{a}}$} \\
\hline \multirow{2}{*}{\multicolumn{2}{|c|}{ Model }} & \multicolumn{2}{|c|}{ Unstandardized Coefficients } & \multirow{2}{*}{$\begin{array}{c}\text { Standardized Coefficients } \\
\text { Beta } \\
\end{array}$} & \multirow[t]{2}{*}{$\mathbf{t}$} & \multirow[t]{2}{*}{ Sig. } \\
\hline & & B & Std. Error & & & \\
\hline \multirow[t]{4}{*}{1} & (Constant) & .620 & 3.318 & & .187 & .852 \\
\hline & Distribution Channels & .118 & .056 & .151 & 2.091 & .039 \\
\hline & Service Quality & .405 & .073 & .398 & 5.522 & .000 \\
\hline & Product Quality & .459 & .070 & .455 & 6.580 & .000 \\
\hline
\end{tabular}

In partial data testing, the variables of distribution channels, service quality, product quality show a positive and significant effect on each variable on purchase decisions at PT Sumatra Sukses Jaya.
Simultaneous Hypothesis Testing (F Test)

The F statistic test basically shows whether all the independent variables included in the model have a simultaneous effect on the dependent variable.

Table 2. Simultaneous Hypothesis Testing (F Test)

\begin{tabular}{|l|l|r|r|r|r|c|}
\hline \multicolumn{7}{|c|}{ ANOVA $^{\mathbf{a}}$} \\
\hline \multicolumn{2}{|l|}{ Model } & Sum of Squares & df & Mean Square & F & Sig. \\
\hline \multirow{2}{*}{1} & Regression & 1461.444 & 3 & 487.148 & 34.255 & $.000^{\mathrm{b}}$ \\
\cline { 2 - 7 } & Residual & 1578.556 & 111 & 14.221 & & \\
\cline { 2 - 7 } & Total & 3040.000 & 114 & & & \\
\hline \multicolumn{6}{|l}{ a. Dependent Variable: Purchase Decisions } \\
\hline \multicolumn{6}{|l}{ bredictors: (Constant), Distribution Channels, Service Quality, Product Quality } \\
\hline
\end{tabular}

In testing the data analysis simultaneously, the variables of distribution channels, service quality, product quality showed a positive and significant effect on purchase decisions at PT Sumatra Sukses Jaya.

\section{CONCLUSION AND SUGGESTION}

In partial data testing, the variables of distribution channels, service quality, product quality show a positive and significant effect on each variable on purchase decisions at PT Sumatra Sukses Jaya. In testing the data analysis simultaneously, the variables of distribution channels, service quality, product quality showed a positive and significant effect on purchase decisions at PT Sumatra Sukses Jaya.
Based on the problems discussed previously, suggestions for the company can be given are:

\section{For Researchers}

From the results of this study, it becomes the basis for looking at the influence between distribution channels, product quality and service quality, which has an impact on purchasing decisions.

2. For the Faculty of Economics, Universitas Prima Indonesia

The results of this study become a model of the results of the study to conduct further research.

\section{For the company}

As a consideration for the improvement of distribution channel problems, product quality in improving purchasing decisions. 


\section{For future researchers}

Can choose other variables for the next research.

\section{Acknowledgement: None}

\section{Conflict of Interest: None}

\section{Source of Funding: None}

\section{REFERENCES}

1. Dharmmesta \& Handoko. (2016). Manajemen Pemasaran Analisis Perilaku Konsumen. Edisi Pertama. BPFE Yogyakarta.

2. Ghozali, Imam. (2013). Aplikasi Analisis Multivariate dengan Program SPSS 21. Semarang: Badan Penerbit Universitas Diponegoro.

3. Girard, Scott L, O'Keefe, Michael F. \& Price, Marc A. (2014). Sales dan Marketing: Menjadi Marketing Andal dan Profesional. Solo: PT. Tiga Serangkai.
4. Hasan, Ali. (2013). Marketing dan Kasuskasus Pilihan. Yogyakarta: CAPS.

5. Manap, Abdul. (2016). Revolusi Manajemen Pemasaran. Yogyakarta: Mitra Wacana Media.

6. Marwanto, Aris. (2015). Marketing Sukses. Yogyakarta: Kobis.

7. Rangkuti, Freddy. (2013). Teknik Membedah Kasus Bisnis Analisis SWOT Cara Perhitungan Bobot, Rating dan OCAI. Jakarta: Gramedia Pustaka.

8. Sujarweni, Wiratna V. (2014). Metodologi Penelitian. Yogyakarta: PT Pustaka Baru.

9. Tjiptono, Fandy \& Chandra, Gregorius. (2017). Pemasaran Strategik. Edisi 3. Yogyakarta: Andi Offset.

How to cite this article: Stewen, Fitriano A, Antono W et.al. Effect of distribution channels, service quality and product quality on purchase decisions at PT Sumatra Sukses Jaya (FDR tire distributor). International Journal of Research and Review. 2021; 8(6): 175-179. DOI: https:// doi.org/10.52403/ijrr.20210621 